\title{
Flora of Baturité, Ceará: a Wet Island in the Brazilian Semiarid
}

\author{
Andréa Pereira Silvera ${ }^{1}$ (1) 0000-0001-6785-5319 \\ Maria Iracema Bezerra Loiola ${ }^{2}$ (D) 0000-0003-3389-5560 \\ Vaneicia dos Santos Gomes ${ }^{3}$ (D) 0000-0002-2357-992X \\ Luiz Wilson Lima-Verde ${ }^{2}$ (1) 0000-0002-6908-1692 \\ Teógenes Senna Oliveira ${ }^{4}$ (1) 0000-0002-9904-6708 \\ Edison Fernandes Silva ${ }^{5}$ (1) 0000-0001-8696-6831 \\ Adriana Tamie Otutumi ${ }^{2}$ (1) 0000-0002-7443-4720 \\ Kátia Araújo Ribeiro ${ }^{2}$ (1) 0000-0003-3002-4049 \\ Francisco Alisson da Silva Xavier6 (1) 0000-0002-8141-2343 \\ Morgana Maria Arcanjo Bruno ${ }^{7}$ (1) 0000-0001-6967-4749 \\ Sarah Sued Gomes Souza ${ }^{2}$ (i) 0000-0001-6943-7401 \\ Francisca Soares Araújo² (10 0000-0003-4661-6137
}

\begin{abstract}
The biota of the humid mountain ranges of the Brazilian semiarid is still poorly understood. In order to fill this scientific gap, we carried out an extensive survey along altitudinal ranges $(400 \mathrm{~m}-1,000 \mathrm{~m})$ on both the windward and the leeward slopes of the Baturité Mountain Range, in the state of Ceará state. We registered 400 plant species and 92 families. The Myrtaceae (36 spp.), Fabaceae (25 spp.), Rubiaceae (20 spp.) and Bromeliaceae (15 spp.) families predominated on the windward slope; while Fabaceae (19 spp.), Myrtaceae (14 spp.) and Euphorbiaceae (11 spp.) were the most abundant on the leeward slope. As we expected, the species richness of trees, shrubs, subshrubs, epiphytes and terrestrial herbs was positively correlated with the altitude $\left(R^{2}>0.60\right)$. Above $800 \mathrm{~m}$, we registered 273 species exclusive to the windward slope, 81 exclusive to the leeward slope, and 46 shared species. Therefore, management actions must consider the spatial heterogeneity, distribution and taxa richness.
\end{abstract}

Keywords: Deciduous Tropical Forest, Evergreen Tropical Forest, Semideciduous Tropical Forest, Steppic Savanna.

\section{INTRODUCTION AND OBJECTIVES}

The mountain ranges in the semiarid domain of Northeastern Brazil stand out from the surrounding flattened landscape expressing a climatic exception (Mantovani et al., 2017; Moro et al., 2015). They occupy approximately $5 \%$ of the northeastern surface, being scattered throughout the states of Ceará, Rio Grande do Norte, Paraíba, Pernambuco, Alagoas and Bahia
(Souza \& Oliveira, 2006). On windward slopes and at higher altitudes, the climate is cooler and wetter, whereas drier climates occur on leeward slopes and at lower altitudes (Nimer, 1989). This climatic variation leads to a spatially heterogeneous flora along the altitudinal gradient, consequently increasing the local species richness (Ferraz \& Rodal, 2006; Homeier et al., 2010).

Evergreen and Semideciduous Forests have been commonly reported along this altitudinal gradient (Rodal \& Sales, 2008;

${ }^{1}$ Universidade Estadual do Ceará (UECE), Itapipoca, CE, Brasil

${ }^{2}$ Universidade Federal do Ceará (UFC), Fortaleza, CE, Brasil

${ }^{3}$ Universidade Estadual do Ceará (UECE), Quixadá, CE, Brasil

${ }^{4}$ Universidade Federal de Viçosa (UFV), Viçosa, MG, Brasil

${ }^{5}$ Universidade Federal do Maranhão (UFMA), São Luís, MA, Brasil

${ }^{6}$ Centro Nacional de Pesquisa de Mandioca e Fruticultura Tropical da Empresa Brasileira de Pesquisa Agropecuária (Embrapa Mandioca e Fruticultura), Cruz das Almas, BA, Brasil

${ }^{7}$ Universidade Católica de Brasília (UCB), Taguatinga, DF, Brasil 
Silva \& Figueiredo, 2013). Since this flora is a remnant of the Brazilian Atlantic Rain Forest (Barbosa et al., 2004), these mountain ranges have been considered a priority for the conservation of Brazilian biodiversity (Lopes et al., 2017; MMA, 2000). Especially in the Brazilian Northeast, the mountainous areas are critically important for the preservation of regional ecosystems, because they represent natural refuges for biota (Silva et al., 2014).

Thirty-five percent $(35 \%)$ of the mountain ranges are located within Ceará State (Sobrinho, 1971), but information on its biota composition is still incipient (Bétard et al., 2007; Kamimura et al., 2017; Lima \& Mansano, 2011). Plant cover and soils of most local wetlands have suffered from intensive and chronic anthropogenic disturbances (Souza \& Oliveira, 2006). Therefore, reports on floristic composition are crucial for implementing sustainable use actions, since the biodiversity degradation on the Baturité Mountain Range has been happening since the colonial period (Mantovani, 2006; Oliveira et al., 2006). Our study shows the need for registering, cataloguing and presenting the biodiversity of such peculiar environments. Thus, we aim to analyze the plant composition and species richness along the altitudinal gradient on the windward and leeward slopes of Baturité Mountain Range, in Ceará State. We also intend to spread information on the local flora and on the protected areas of Northeastern Brazil.

\section{MATERIALS AND METHODS}

\subsection{Study site}

The Baturité Mountain Range is a residual relief with an extension of $800 \mathrm{~km}^{2}$ and moderate altitudes (800 $1,115 \mathrm{~m}$ ). It is a Precambrian crystalline complex located in the northeast of Ceará State, $70 \mathrm{~km}$ from the coast (Bétard et al., 2007; Souza \& Oliveira, 2006). From the elevation of $600 \mathrm{~m}$ up, the mountain range is a strict protected area, the APA de Baturité. The first protected area was established by state law no. 20,956, on September 18, 1990, which was later altered by state law no. 27,290, on December 15, 2003. Currently, it encompasses 32,690 hectares.

Both the altitude and the geographical position favor an orographic effect at the top and on the windward slope (north-eastward) of the mountain, whereby a humidity of $>1,000 \mathrm{~mm} \times$ year $^{-1}$ is carried by South Atlantic trade winds. On the leeward slope (westward), the precipitation is below 1,000 mm $\times$ year $^{-1}$ (Mantovani, 2006; Santos et al., 2012; Souza \& Oliveira, 2006). In order to register the local species composition and richness, we selected three well-conserved areas on each slope, at the following altitudinal ranges: 400 $600 \mathrm{~m}$ a.s.l., 600 - $800 \mathrm{~m}$ a.s.l. and above $800 \mathrm{~m}$ a.s.l. We chose these areas in order to comprise the climatic and physiognomic variations along the altitudinal range on both slopes (Table 1).

Table 1. Location and characterization of the studied areas on the Baturité Mountain Range, Ceará State, Brazil.

\begin{tabular}{|c|c|c|c|}
\hline $\begin{array}{l}\text { Location - municipality - } \\
\text { coordinates }\end{array}$ & $\begin{array}{c}\text { Vegetation }{ }^{*}-\text { altitude - slope - } \\
\text { precipitation }\end{array}$ & $\begin{array}{c}\text { Soil type } \\
\text { (Oliveira et al., 2006) }\end{array}$ & Species richness per $G^{* *}$ \\
\hline $\begin{array}{l}\text { Salva-Vidas } \\
\text { Guaramiranga } \\
4^{\circ} 15^{\prime} 32^{\prime \prime} \mathrm{S} \\
38^{\circ} 58^{\prime} 1,3 \text { " W }\end{array}$ & $\begin{array}{c}\text { FSS - SDSF } \\
400-600 \mathrm{~m} \\
\text { Leeward } \\
608 \mathrm{~mm}\end{array}$ & $\begin{array}{c}\text { Cambic eutrophic red } \\
\text { argisol }\end{array}$ & $\begin{array}{c}\text { tre }=29 ; \operatorname{shr}=16 ; \text { subshr }=01 \\
\text { vi }=01 ; \text { th }=01 ; \text { eh }=01 ; \mathrm{hm}=00\end{array}$ \\
\hline $\begin{array}{c}\text { Jardim } \\
\text { Mulungu } \\
4^{\circ} 17^{\prime} 10^{\prime \prime} \mathrm{S} \\
39^{\circ} 00^{\prime} 3,8^{\prime \prime} \mathrm{W}\end{array}$ & $\begin{array}{c}\text { SDMF } \\
600-800 \mathrm{~m} \\
\text { Leeward } \\
1,130 \mathrm{~mm}\end{array}$ & $\begin{array}{l}\text { Abruptic eutrophic } \\
\text { yellow argisol }\end{array}$ & $\begin{array}{c}\text { tre }=66 ; \text { shr }=19 ; \text { subshr }=04 ; \\
\text { vi }=02 ; \text { th }=10 ; \text { eh }=00 ; \mathrm{hm}=00\end{array}$ \\
\hline $\begin{array}{c}\text { Lagoa } \\
\text { Guaramiranga } \\
4^{\circ} 12^{\prime} 21 " \mathrm{~S} \\
38^{\circ} 58^{\prime} 16^{\prime \prime} \mathrm{W}\end{array}$ & $\begin{array}{c}\text { SEMF } \\
>800 \mathrm{~m} \\
\text { Leeward } \\
1,646 \mathrm{~mm}\end{array}$ & Humic sandy soil & $\begin{array}{l}\text { tree }=105 ; \text { shr }=30 ; \text { subshr }=04 ; \\
\text { vi }=06 ; \text { th }=19 ; \text { eh }=14 ; \mathrm{hm}=01\end{array}$ \\
\hline $\begin{array}{l}\text { Arvoredo } \\
\text { Guaramiranga } \\
4^{\circ} 13^{\prime} 50^{\prime \prime} \mathrm{S} \\
38^{\circ} 55^{\prime} 54^{\prime \prime} \mathrm{W}\end{array}$ & $\begin{array}{c}\text { SEMF } \\
>800 \mathrm{~m} \\
\text { Windward } \\
1,646 \mathrm{~mm}\end{array}$ & $\begin{array}{l}\text { Dystrophic yellow } \\
\text { Argisol }\end{array}$ & $\begin{array}{c}\text { tre }=84 ; \operatorname{shr}=28 ; \text { subshr }=05 \\
\text { vi }=00 ; \text { th }=20 ; \text { eh }=10 ; \mathrm{hm}=00\end{array}$ \\
\hline $\begin{array}{c}\text { Sinimbu } \\
\text { Guaramiranga } \\
4^{\circ} 17^{\prime} 49^{\prime \prime} \mathrm{S} \\
38^{\circ} 55^{\prime} 59^{\prime \prime} \mathrm{W}\end{array}$ & $\begin{array}{c}\text { SEMF } \\
600-800 \mathrm{~m} \\
\text { Windward } \\
1,471 \mathrm{~mm}\end{array}$ & $\begin{array}{l}\text { Dystrophic yellow } \\
\text { latosol }\end{array}$ & $\begin{array}{c}\text { tre }=74 ; \operatorname{shr}=21 ; \text { subshr }=00 ; \\
\text { vi }=08 ; \text { th }=15 ; \text { eh }=06 ; \mathrm{hm}=02\end{array}$ \\
\hline $\begin{array}{c}\text { Taveiras } \\
\text { Baturité } \\
4^{\circ} 17^{\prime} 54^{\prime \prime} \mathrm{S} \\
38^{\circ} 55^{\prime} 10^{\prime \prime} \mathrm{W}\end{array}$ & $\begin{array}{c}\text { SSSF } \\
400-600 \mathrm{~m} \\
\text { Windward } \\
1,079 \mathrm{~mm}\end{array}$ & $\begin{array}{l}\text { Typical dystrophic } \\
\text { haplic Tb Cambisol }\end{array}$ & $\begin{array}{c}\text { tre }=77 ; \text { shr }=14 ; \text { subshr }=01 ; \\
\text { vi }=00 ; \text { th }=05 ; \text { eh }=05 ; \mathrm{hm}=03\end{array}$ \\
\hline
\end{tabular}

* FSS: Forested Steppic Savanna "caatinga”; SDSF: Seasonal Deciduous Submountain Forest "dry forest”; SDMF: Seasonal Deciduous Mountain Forest "dry forest”; SEMF: Seasonal Evergreen Mountain Forest "humid mountain forest”; SSSF: Seasonal Semidecidous Submountain Forest "humid mountain forest” (according IBGE, 2012). ${ }^{* *}$ GF: growth form; tre: tree; shr: shrub; subshr: subshrub; vi: vine; th: terrestrial herb; eh: epiphytic herb; hm: hemiparasite. 
The Forested Steppic Savanna (FSS; “Caatinga") is composed of a thorny deciduous vegetation, predominant at lower altitudes. Along the altitudinal range, the FSS is gradually replaced by a forest vegetation along the altitudinal range. On the windward slope, there are: i) a Seasonal Semidecidous Submountain Forest (SSSF) $400-600$ m; and ii) a Seasonal Evergreen Mountain Forest (SEMF) above $600 \mathrm{~m}$. On the leeward slope, there are: i) a transition from the FSS to the SDSF (Seasonal Deciduous Submountain Forest) 400 $600 \mathrm{~m}$; ii) a Seasonal Deciduous Mountain Forest (SDMF) 600 - $800 \mathrm{~m}$; and iii) a Seasonal Evergreen Mountain Forest (SEMF) above $800 \mathrm{~m}$ (see Table 1).

\subsection{Data collection}

In order to list the plants, we sampled 200 quadrants in each of the six areas, according to the procedures suggested by Araújo et al. (2006). In addition, we completed our list researching the samples of the EAC Herbarium of the Universidade Federal do Ceará. We also revised and updated the taxonomic identifications with the aid of specialists from the following herbaria: EAC, PEUFR, IPA and CEPEC. The taxonomic classification that we used follows the APG IV system (2016). The names of botanical families, genera, species and authorships were confirmed in the International Plant Names Index (Royal Botanic Gardens, Kew et al., 2015) and in the list of Brazilian Flora 2020 (JBRJ, 2016).

To categorize the vegetation physiognomy, we used Whittaker's classification of plant growth forms (1975). The growth forms are adequate indicators of communities, since they can reflect global and local climatic conditions. We adjusted Whittaker's (1975) system as following: i) trees: $>3 \mathrm{~m}$-height woody plants; ii) shrubs: > $3 \mathrm{~m}$-height woody plants with main branches developing at approximately $50 \mathrm{~cm}$ above ground; iii) subshrubs: $<2$ m-height plants with a woody main stem and herbaceous secondary branching; iv) terrestrial herbs: land plants with herbaceous aerial stems; v) epiphytes: plants with herbaceous stems that use other plants as support; vi) vines: plants with prolonged stems that twine around a substrate; and vii) hemiparasites: photosynthetic plants that withdraw sap from their host plants.

We obtained precipitation data from the Fundação Cearense de Meteorologia e Recursos Hídricos (FUNCEME, 2017), at the following local stations, close to our studied areas: Baturité-n22, Pacoti-n105, Guaramiranga-54, Mulungu-n98 and Caridade-n31. Data showed a seasonal rainfall regime with precipitation concentrated from January to May, driven by the Intertropical Convergence Zone. However, stations located at distinct altitudes and different mountain slopes showed remarkable differences in the annual rainfall regime.
Greater precipitation was found in the northeastern slope and at higher portions of the mountain range. The soil classification of the studied areas followed that of Oliveira et al. (2006). Altitudinal ranges and coordinates were measured in the field with a GPS navigation device (Table 1).

\subsection{Data analysis}

We organized our list by family, species, vernacular name, growth form, altitudinal range, phytophysiognomy and collector number. Samples are deposited at EAC. We estimated the global richness, as well as the richness at family and species levels, and by phytophysiognomy. We analyzed the relationship between species richness, growth form (dependent variable), and altitude (independent or predictive variable) through a simple linear regression using the Bioestat 5.0 Software (Ayres et al., 2007)

\section{RESULTS AND DISCUSSION}

We registered 400 morphospecies distributed within 92 families. A total of 23 taxa (13\%) were identified only to the genus due to the lack of or inadequacy of reproductive organs. The families with greatest species richness were Myrtaceae (43 spp.), Fabaceae (38 spp.), Euphorbiaceae (21 spp.), Rubiaceae (20 spp.), Melastomataceae (14 spp.), and Bromeliaceae, Erythroxylaceae and Orchidaceae, with 10 species each (Appendix A). The high richness of vascular plants confirms the documented pattern for mountainous areas of the Brazilian semiarid: they are more diverse than the surrounding Caatinga, since they contain a mix of Caatinga and Atlantic Forest species (Carnaval et al., 2009; Leite et al., 2016; Lopes et al., 2017). In addition, the richness of 400 species of vascular plants, found on the Baturité Mountain Range, is higher than the species richness registered for other similar Brazilian forests, e.g., Pau-Ferro Ecological Reserve, with 309 species, in Paraíba State (Barbosa et al., 2004), Brejo Madre de Deus, with 293 species, in Pernambuco State (Nascimento et al., 2012) and Meruoca Sierra, with 100 species, in Ceará State (Silva \& Figueiredo, 2013), highlighting the importance of this montane forests for the conservation of tropical biodiversity.

Our results show that the richness increases towards the top of the mountain, and that it is greater on the windward slope at the Evergreen Forest. We registered a total of 255 species (64\%) and 69 families (75\%) at higher altitudes, above $800 \mathrm{~m}$ in the Baturité Mountain Range - joined data from Arvoredo and Lagoa sites. On the windward slope, below $800 \mathrm{~m}$-on Sinimbu and Taveiras sites together-, we registered 175 species (44\%) and 62 families (67\%); whereas, on the leeward slope, 
below $800 \mathrm{~m}$-on Jardim and Salva-Vidas sites together-, we registered 127 species (32\%) and 50 families (54\%) (Appendix A). Such differences reflect the combined effects of ocean winds, altitudinal variation and position of the slope. These results also corroborate the pattern documented by Lopes et al. (2008), Lima et al. (2011), Kamimura et al., (2017) and BFG (2015), that indicates dry forests have significantly less species and families compared to humid-forests.

In the Seasonal Evergreen Forest located both on the windward and leeward slopes-above $600 \mathrm{~m}$ and $800 \mathrm{~m}$, respectively (Table 1 ) - , the most diverse families were Myrtaceae (36 spp.), Fabaceae (25 spp.), Rubiaceae (20 spp.), Bromeliaceae (15 spp.), Melastomataceae (14 spp.), Euphorbiaceae (13 spp.) and Orchidaceae (10 spp.). On the leeward slope, where a Seasonal Deciduous Forest and a Forested Steppic Savanna predominate, Fabaceae (19 spp.), Myrtaceae (14 spp.) and Euphorbiaceae (11 spp.) were the most diverse families. In the Fabaceae family, the subfamilies presented distinct species richness on windward and leeward slopes. In the former, Mimosoideae (8 spp.) and Faboideae (7 spp.) predominated, whereas in the latter the most representative were Mimosoideae (13 spp.) and Caesalpinioideae (11 spp.).

In the Baturité Mountain Range leeward slope, where Deciduous Forests and Forested Savannas were the most representative (see Alcoforado-Filho et al., 2003; Cestaro \& Soares, 2004; Ferraz et al., 2004), the subfamilies Mimosoideae and Caesalpinioideae, predominated. Even though Myrtaceae was among the most diverse families on the leeward slope, its richness was higher on the windward slope. Furthermore, most of its species (84\%) occur above $600 \mathrm{~m}$, indicating that the richness of Myrtaceae in the Brazilian semiarid is more associated with areas with higher water availability than with the surrounding Caatinga. The area of occurrence of Myrtaceae in the Evergreen Forest, both on the windward and on the leeward slopes, above $600 \mathrm{~m}$ and $800 \mathrm{~m}$, respectively, confirms the pattern reported by Peixoto \& Gentry (1990), also observed in the Atlantic Domain as a whole. Furthermore, Myrtaceae, Fabaceae, Rubiaceae, Bromeliaceae, Melastomataceae, Euphorbiaceae and Orchidaceae are abundant in Tropical Rainforests as well, including lowland and highland Seasonal Evergreen Forests in the States of Pernambuco and Paraíba (Rodal \& Nascimento, 2002; Andrade \& Rodal, 2004; Barbosa et al., 2004; Ferraz \& Rodal, 2006; Nascimento et al., 2012; Rodal \& Sales, 2008). Species and family similarities to this type of forest are likely associated with water availability on the soil, from rainfall or dew.

Aspidosperma pyrifolium Mart., Bauhinia cheilantha (Bong.) Steud., Cordia glazioviana (Taub.) Gottschling \& J. S. Mill., Croton blanchetianus Baill., and Mimosa caesalpiniifolia Benth. occurred below $600 \mathrm{~m}$ on the windward slope. These taxa are commonly found in the Caatinga. Some species are strictly distributed in wetter areas, above $800 \mathrm{~m}$ on the windward slope and above $600 \mathrm{~m}$ on the leeward slope, such as: Albizia polycephala (Benth.) Killip ex Record, Apeiba tibourbou Aubl., Byrsonima crispa A. Juss., Cassia ferruginea (Schrad.) Schrad. ex DC. var. ferruginea, Cupania racemosa (Vell.) Radlk., Guazuma ulmifolia Lam., Inga marginata Willd., Myrciaria ferruginea O.Berg, Ouratea polygyna Engl., Podocarpus sellowii Klotzsch ex. Endl., Pouteria macrophylla (Lam.) Eyma, Vismia guianensis (Aubl.) Choisy and Zanthoxylum rhoifolium Lam. We note that Podocarpus sellowii was found at one collecting site only (Arvoredo). At lower altitudes of the windward slope, some exclusive species occurred, such as: Alchornea glandulosa subsp. iricurana (Casar.) Secco, Attalea speciosa Mart. ex Spreng., Casearia grandiflora Cambess., Chrysophyllum gonocarpus (Mart. \& Eichler ex Miq.) Engl., Coccoloba parimensis Benth., Coussarea contracta (Walp.) Müll.Arg. var. contracta, Oreopanax capitatus (Jacq.) Decne. \& Planch., Parkia pendula (Willd.) Benth. ex Walp., Protium warmingianum Marchand., Pseudobombax marginatum (A.St.-Hil.) A. Robyns and Zizyphus undulata Reissek.

Concerning growth forms, the studied flora was composed of 214 trees (54\%), 82 shrubs, 49 terrestrial herbs, 23 epiphytic herbs, 18 vines, 10 subshrubs and 4 hemiparasites. There was a positive correlation between altitude and richness of trees, shrubs, subshrubs, epiphytic herbs and terrestrial herbs $\left(\mathrm{R}^{2}>0.60\right.$ and $\left.p<0.05\right)$. However, for vines and hemiparasites, the correlation was not statistically significant (Figure 1). The richness of tree species is one of the most striking characteristics of the Tropical Forest typologies, a pattern documented in other Brazilian Atlantic forests (BFG, 2015; Nascimento et al., 2012).

The species richness and composition found in our study showed that, on the windward slope above $600 \mathrm{~m}$, and on the leeward slope above $800 \mathrm{~m}$, the flora is more similar. In contrast, below these altitudinal levels, on both slopes, the flora differed. The positive correlation between diversity and altitude is likely a response to greater water availability in higher elevations of the altitudinal gradient. The mountains of Northeastern Brazil are relatively low, with some altitudes of approximately 1,000 $\mathrm{m}$ a.s.l. However, they have a more favorable water balance, milder temperatures, and lower rates of evapotranspiration and evening condensation than the lower area of the countryside depression (Mantovani et al., 2017; Moro et al., 2015; Souza \& Oliveira, 2006). This may explain why the plant species richness in the semiarid domain of Northeastern Brazil increases with higher altitudes.

It is also worth mentioning that the greater richness of epiphytic herbs (18 out of 23 species) at altitudes above $800 \mathrm{~m}$ reflects a higher humidity. According to Gentry (1988), there is a positive correlation between diversity and 
precipitation in the Neotropical Region. In addition, our results are in accordance with those found in other studies on the Mountain Forests of Pernambuco State (Ferraz et al., 1998; Ferraz et al., 2003; Rodal \& Nascimento, 2002). According to Ferraz et al. (2004) and Lopes et al. (2008),
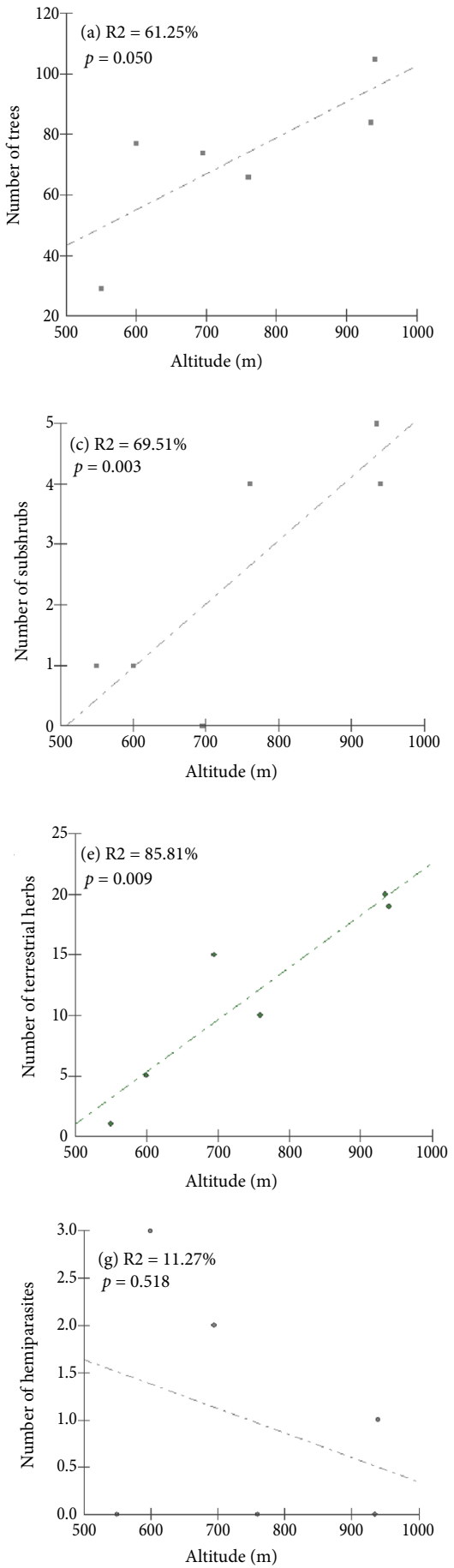

under similar climatic and edaphic regimes, the Evergreen and the Semidecidous Montane Forests can be found closely associated in Northeastern Brazil, but demonstrate different floristic and structural compositions. Thus, protection efforts must contemplate both humid and dry forest areas.
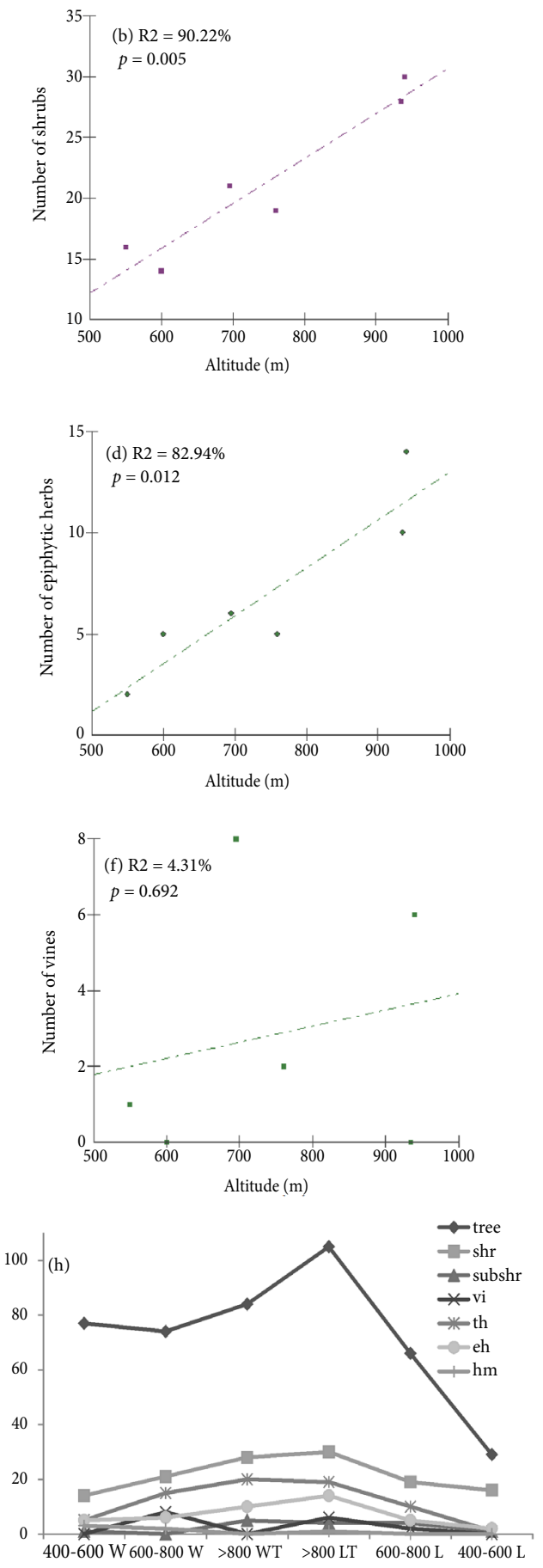

Figure 1. Linear regression of altitude and number of plants of each growth form [(a), (b), (c), (d), (e), (f), (g)] and dispersion diagrams (h) of plants.

shr: shrub; subshr: subshrub; vi: vine; th: terrestrial herb; eh: epiphytic herb; hm: hemiparasite; W: windward; L: leeward; T: top. 


\section{CONCLUSION}

In conclusion, 273 species (68\%) were found exclusively at the top of the mountain and on the windward slope; 81 species (20\%) were exclusively found on the leeward slope; and 46 species (12\%) were found on both slopes, with a total of 400 species on the Baturité Mountain Range, in Ceará State. Our results highlight that the management actions, the restoration of degraded areas and the establishment of integral conservation on the Baturité Mountain Range must consider the spatial heterogeneity described in our work; that is, the differential plant distribution and richness both along the altitudinal gradient and between slope positions. Adequate conservation efforts should consider the total richness and the local heterogeneity.

\section{ACKOWLEGMENTS}

We are grateful to the taxonomists who gently identified the botanical material; to the land owners for allowing the data collection (Arvoredo, Lagoa, Sinimbu, Labirinto dos Taveiras, Jardim and Salva-Vidas sites); and to the Companhia de Eletricidade do Estado do Ceará (COELCE) for funding this study. Special thanks to teacher Maria Angélica Figueiredo (in memory), idealizer of the studies referring to Flora of Ceara, in special of the mountain range of Baturite.

\section{SUBMISSION STATUS}

Received: 28 June 2018

Accepted: 7 Nov. 2018

Associate editor: Rodrigo Studart Corrêa

(D) 0000-0002-9422-2629

\section{CORRESPONDENCE TO}

\section{Andréa Pereira Silvera}

Universidade Estadual do Ceará (UECE), Faculdade de Educação de Itapipoca, Av. da Universidade, s/n, Madalena, CEP 62205-090, Itapipoca, CE, Brasil

e-mail: andrea.silveira@uece.br

\section{FINANCIAL SUPPORT}

Companhia de Eletricidade do Estado do Ceará (COELCE).

\section{REFERENCES}

Alcoforado-Filho FG, Sampaio EVSB, Rodal MJN. Florística e fitossociologia de um remanescente de vegetação caducifólia espinhosa arbórea em Caruaru, Pernambuco. Acta Botanica Brasilica 2003; 17(2): 287-303. 10.1590/S0102-33062003000200011

Andrade KVSA, Rodal MJN. Fisionomia e estrutura de um remanescente de floresta estacional semidecidual de terras baixas no nordeste do Brasil. Revista Brasileira de Botânica 2004; 27(3): 463-474. 10.1590/S0100-84042004000300007

Angiosperm Phylogeny Group - APG IV. An udpdate of the Angiosperm Phylogeny Group classification for the orders and families of flowering plants: APG IV. Botanical Journal of the Linnean Society 2016; 181: 1-20. 10.1111/boj.12385

Araújo FS, Gomes VS, Silveira AP, Figueiredo MA, Oliveira RF, Bruno MMA et al. Efeito da variação topoclimática na fisionomia e estrutura da vegetação da serra de Baturité, Ceará. In: Oliveira TS, Araújo FS, editors. Diversidade e conservação da Biota na Serra de Baturité, Ceará. Fortaleza: Edições UFC-COELCE; 2006. p. 75-136.

Ayres M, Ayres M Jr, Ayres DL, Santos ADA. Bioestat 5.0: aplicações estatísticas nas áreas das ciências bio-médicas. Belém: Instituto Mamirauá; 2007.

Barbosa MRDV, Agra MDF, Sampaio EVSB, Cunha JD, Andrade LD. Diversidade florística na Mata do Pau-Ferro, Areia, Paraíba. Brasília: Ministério do Meio Ambiente; 2004 [cited 2019 Oct. 29]. p. 111-122. Available from: https://bit.ly/2WFrhMI

Bétard F, Peulvast JP, Claudino-Sales V. Caracterização morfopedólogica de uma serra úmida no semi-árido do nordeste brasileiro: o caso do Maciço de Baturité-CE. Mercator-Revista de Geografia da UFC 2007; 6(12): 107-126.

Brazil Flora Group - BFG. Growing knowledge: an overview of seed plant diversity in Brazil. Rodriguésia 2015; 66: 1085-1113. 10.1590/2175-7860201566411

Carnaval AC, Hickerson MJ, Haddad CFB, Rodrigues MT, Moritz C. Stability predicts genetic diversity in the Brazilian Atlantic forest hotspot. Science 2009; 323(5915): 785-789. 10.1126/science.1166955

Cestaro LA, Soares JJ. Variações florística e estrutural e relações fitogeográficas de um fragmento de floresta decídua no Rio Grande do Norte, Brasil. Acta Botanica Brasilica 2004; 18(2): 203-218. 10.1590/S0102-33062004000200001

Ferraz EMN, Araújo EL, Silva SI. Floristic similarities between lowland and montane areas of Atlantic Coastal Forest in Northeastern Brazil. Plant Ecology 2004; 174(1): 59-70.

Ferraz EMN, Rodal MJN. Caracterização fisionômica-estrutural de um remanescente de floresta ombrófila montana de Pernambuco, Brasil. Acta Botanica Brasilica 2006; 20(4): 911-926. 10.1590/S010233062006000400015

Ferraz EMN, Rodal MJN, Sampaio EVSB. Physiognomy and structure of vegetation along an altitudinal gradient in the semiarid region of northeastern Brazil. Phytocoenologia 2003; 33(1): 71-92. 10.1127/0340-269X/2003/0033-0071

Ferraz EMN, Rodal MJN, Sampaio EVSB, Pereira RDCA. Composição florística em trechos de vegetação de caatinga e brejo de altitude na região do Vale do Pajeú, Pernambuco. Brazilian Journal of Botany 1998; 21(1): 7-15. 10.1590/S0100-84041998000100002

Fundação Cearense de Meteorologia e Recursos Hídricos - Funceme. Dados dos postos pluviométricos do Ceará. 2017 [cited 2019 Oct. 29]. Available from: https://bit.ly/2LzMrWm

Gentry AH. Changes in plant community diversity and floristic composition on environmental and geographical gradients. Annals of the Missouri Botanical Garden 1988; 75(1): 1-34. 10.2307/2399464 
Homeier J, Breckle SW, Günter S, Rollenbeck RT, Leuschner C. Tree diversity, forest structure and productivity along altitudinal and topographical gradients in a species-rich Ecuadorian montane rain forest. Biotropica 2010; 42(2): 140-148. 10.1111/j.17447429.2009.00547.x

Instituto Brasileiro de Geografia e Estatística - IBGE. Manual técnico da vegetação brasileira. Rio de Janeiro: IBGE; 2012.

Jardim Botânico do Rio De Janeiro - JBRJ. Flora do Brasil 2020 em construção. Rio de Janeiro: Jardim Botânico do Rio de Janeiro; 2016 [cited 2019 Oct. 29]. Available from: http://floradobrasil.jbrj.gov.br

Kamimura VA, Moraes PLR, Ribeiro HL, Joly CA, Assis MA. Tree diversity and elevational gradient: the case of Lauraceae in the Atlantic Rainforest. Flora 2017; 234: 84-91. 10.1016/j. flora.2017.05.013

Leite YLR, Costa LP, Loss AC, Rocha RG, Batalha-Filho H, Bastos AC et al. Neotropical forest expansion during the last glacial period challenges refuge hypothesis. PNAS 2016; 113(4): 1008-1013. $10.1073 /$ pnas. 1513062113

Lima JR, Mansano VDF. A família Leguminosae na Serra de Baturité, Ceará, uma área de Floresta Atlântica no semiárido brasileiro. Rodriguésia 2011; 62(3): 563-613. 10.1590/2175-7860201162309

Lima JR, Sampaio EVSB, Rodal MJN, Araújo FS. Physiognomy and structure of a seasonal deciduous forest the Ibiapaba plateau, Ceará, Brazil. Rodriguésia 2011; 62(2): 379-389. 10.1590/21757860201162212

Lopes CGR, Ferraz EMN, Araújo EL. Physiognomic-structural characterization of dry-and humid-forest fragments (Atlantic Coastal Forest) in Pernambuco State, NE Brazil. Plant Ecology 2008; 198(1): 1-18. 10.1007/s11258-007-9380-Z

Lopes SDF, Ramos MB, Almeida GRD. The role of mountains as refugia for biodiversity in Brazilian Caatinga: conservationist implications. Tropical Conservation Science 2017; 10: 1-12. $10.1177 / 1940082917702651$

Mantovani W. Conservação de biodiversidade: importância das serras úmidas no Nordeste semi-árido brasileiro. In: Oliveira TS, Araújo FS, editors. Diversidade e conservação da biota na Serra de Baturité, Ceará. Fortaleza: Edições UFC-COELCE; 2006. p. 3-15.

Mantovani W, Anjos L, Monteiro RF, Araujo FS. A conservação da biodiversidade no domínio caatinga. In: Mantovani W, Monteiro RF, Anjos L, Cariello MO, editors. Pesquisas em unidades de conservação no domínio da Caatinga subsídios à gestão. Fortaleza: Edições UFC; 2017. p. 81-122.

Ministério do Meio Ambiente - MMA. Avaliação e ações prioritárias para a conservação da biodiversidade da floresta atlântica e campos sulinos. Brasília: MMA/SBF; 2000.
Moro MF, Macedo MB, Moura-Fé MM, Castro AS, Costa RC. Vegetação, unidades fitoecológicas e diversidade paisagística do estado do Ceará. Rodriguésia 2015; 66(3): 717-743. 10.1590/21757860201566305

Nascimento LM, Rodal MJN, Silva AG. Florística de uma floresta estacional no Planalto da Borborema, nordeste do Brasil. Rodriguésia 2012; 63(2): 429-440. 10.1590/S2175-78602012000200015

Nimer E. Climatologia do Brasil. 2nd ed. Rio de Janeiro: IBGESUPREN; 1989.

Oliveira TS, Figueiredo MA, Nogueira RS, Sousa SC, Souza SSG, Romero RE. Histórico dos impactos antrópicos e aspectos geoambientais da serra de Baturité, Ceará. In: Oliveira TS, Araújo FS, editors. Diversidade e conservação da biota na Serra de Baturité, Ceará. Fortaleza: Edições UFC-COELCE; 2006. p. 19-70.

Peixoto AL, Gentry A. Diversidade e composição florística da mata de tabuleiro na Reserva Florestal de Linhares (Espírito Santo, Brasil). Revista Brasileira de Botânica 1990; 13(1): 19-25.

Rodal MJ, Nascimento LM. Levantamento florístico da floresta serrana da reserva biológica de Serra Negra, microrregião de Itaparica, Pernambuco, Brasil. Acta Botanica Brasilica 2002; 16(4): 481-500. 10.1590/S0102-33062002000400009

Rodal MJN, Sales MF. Panorama of the montane forests of Pernambuco, Brazil. In: Thomas WW, editor. The Atlantic coastal forest of northeastern Brazil. New York: Botanical Garden Press; 2008. p. 541-559.

Royal Botanic Gardens, Kew; Harvard University Herbaria \& Libraries; \& Australian National Botanic Gardens. International Plant Names Index [Internet]. 2015 [cited 2019 Oct. 29]. Available from: http://www.ipni.org

Santos FLA, Medeiros EM, Souza MJN. Contexto hidroclimático do enclave úmido do maciço de Baturité-Ceará: potencialidades e limitações ao uso da terra. Revista Geonorte 2012; 3(9): 1056-1065.

Silva FKG, Lopes FS, Lopez LCS, Melo JIM, Trovão DMDBM. Patterns of species richness and conservation in the Caatinga along elevational gradients in a semiarid ecosystem. Journal of Arid Environments 2014; 110, 47-52. 10.1016/j.jaridenv.2014.05.011

Silva MEA, Figueiredo MF. Flora fanerogâmica de um enclave úmido no Ceará: Serra da Meruoca. Enciclopédia Biosfera 2013; 9(17): 2811-2820.

Souza MJN, Oliveira VPV. Os enclaves úmidos e sub-úmidos do semi-árido do nordeste brasileiro. Revista Mercator 2006; 5(9): 85-102.

Vasconcelos Sobrinho J. As regiões naturais do Nordeste, o meio a civilização. Recife: Conselho do Desenvolvimento de Pernambuco; 1971.

Whittaker RH. Communities and ecosystems. 2nd ed. New York: Macmillan; 1975. 


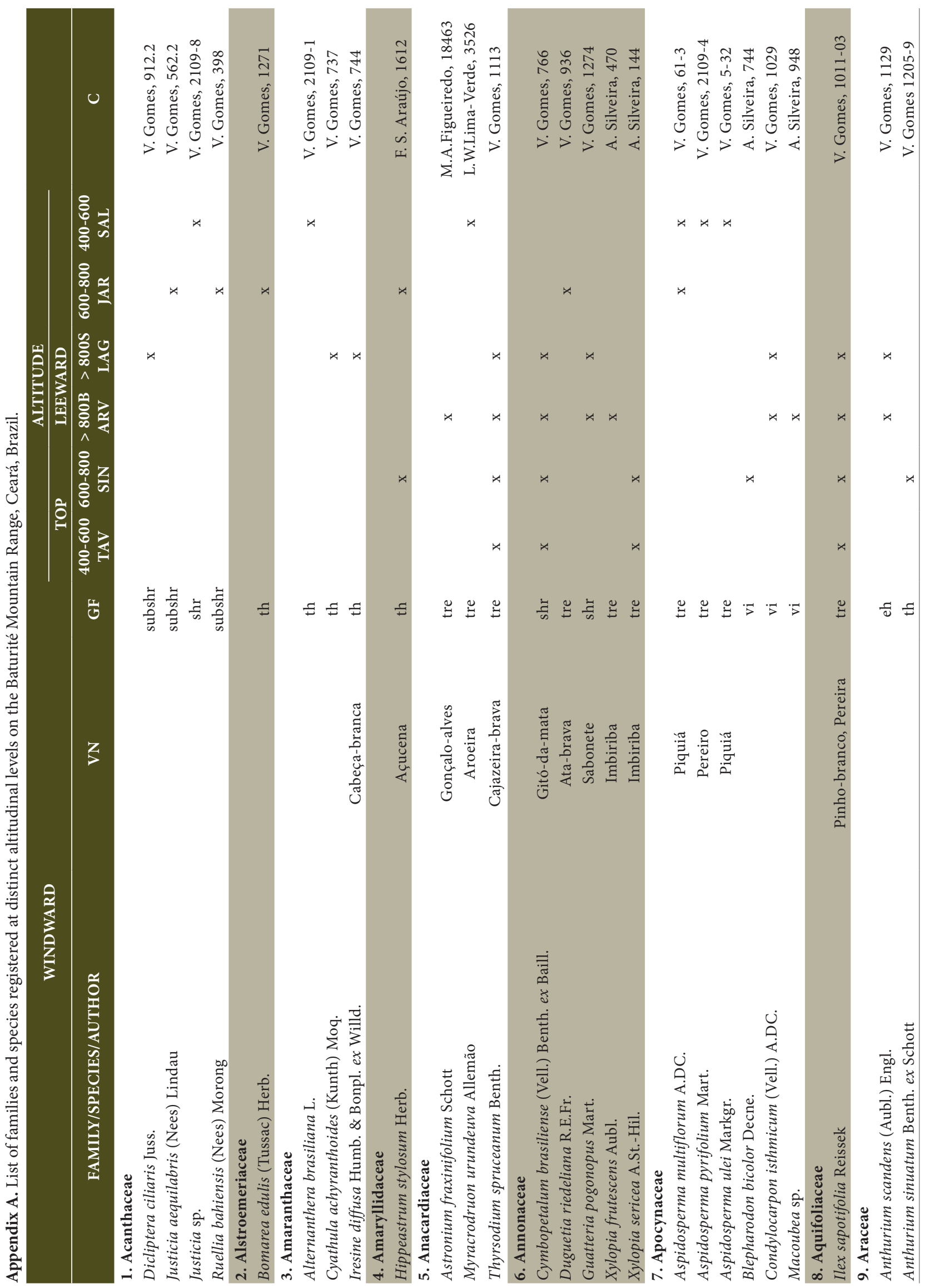




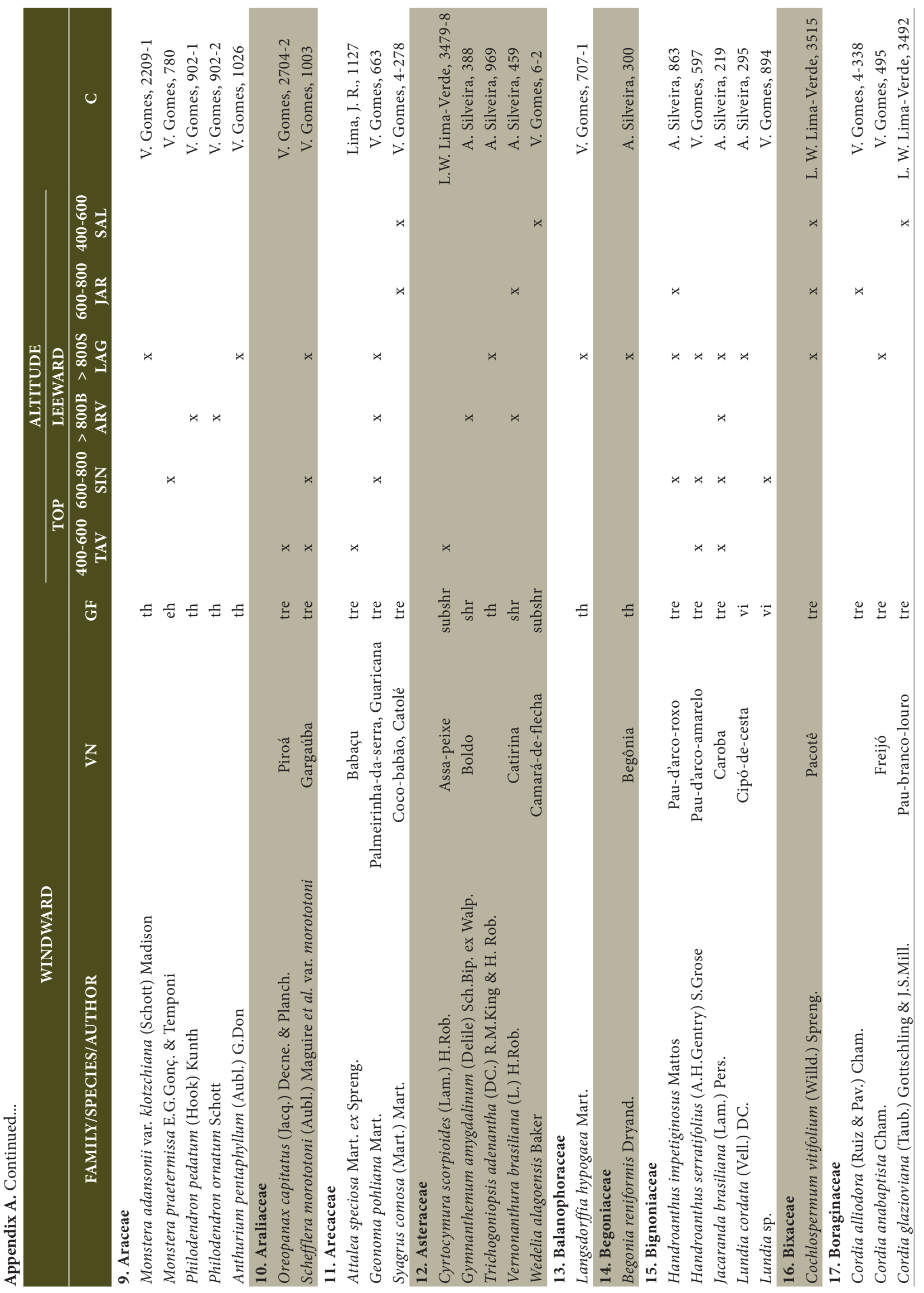




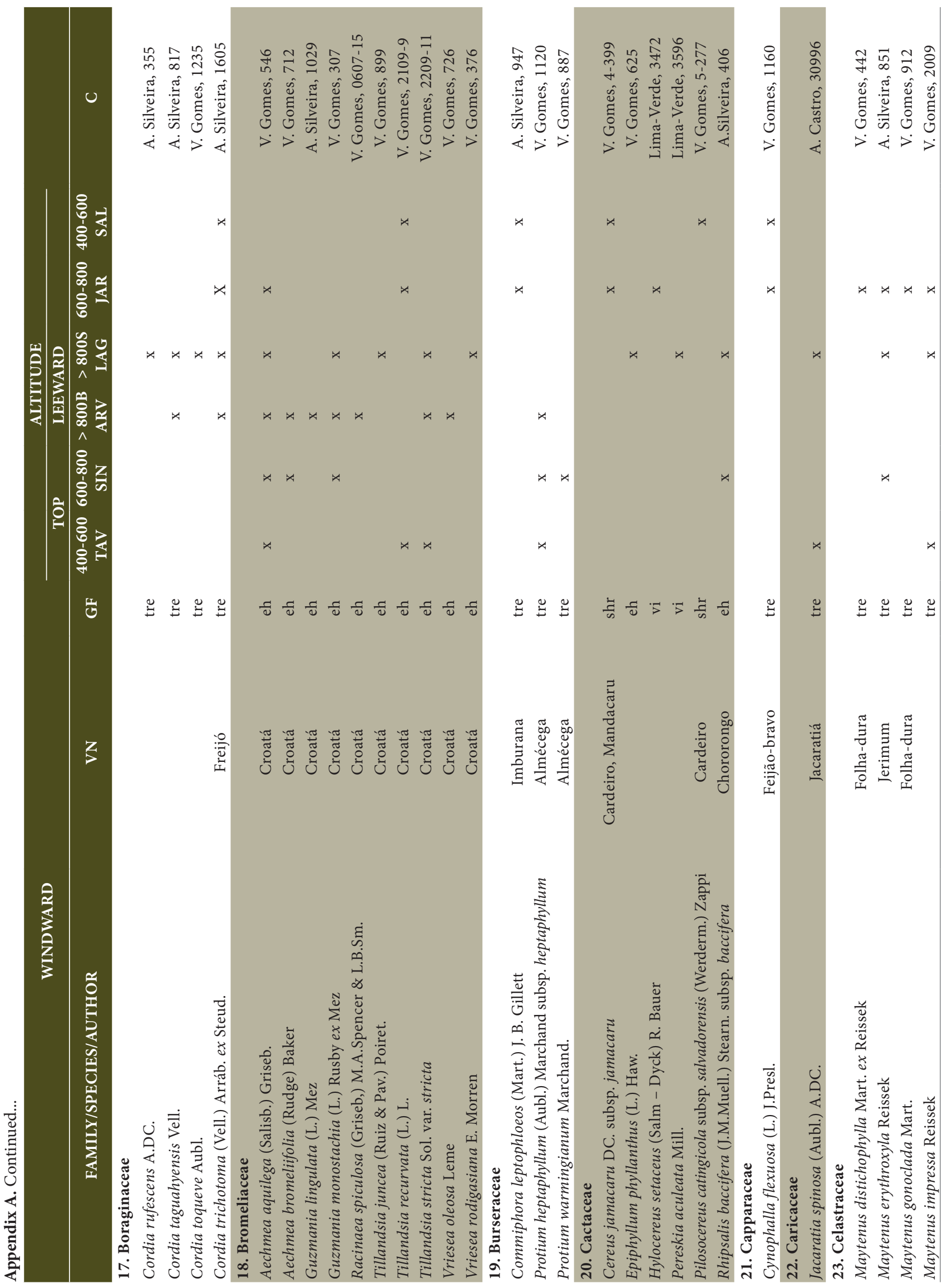




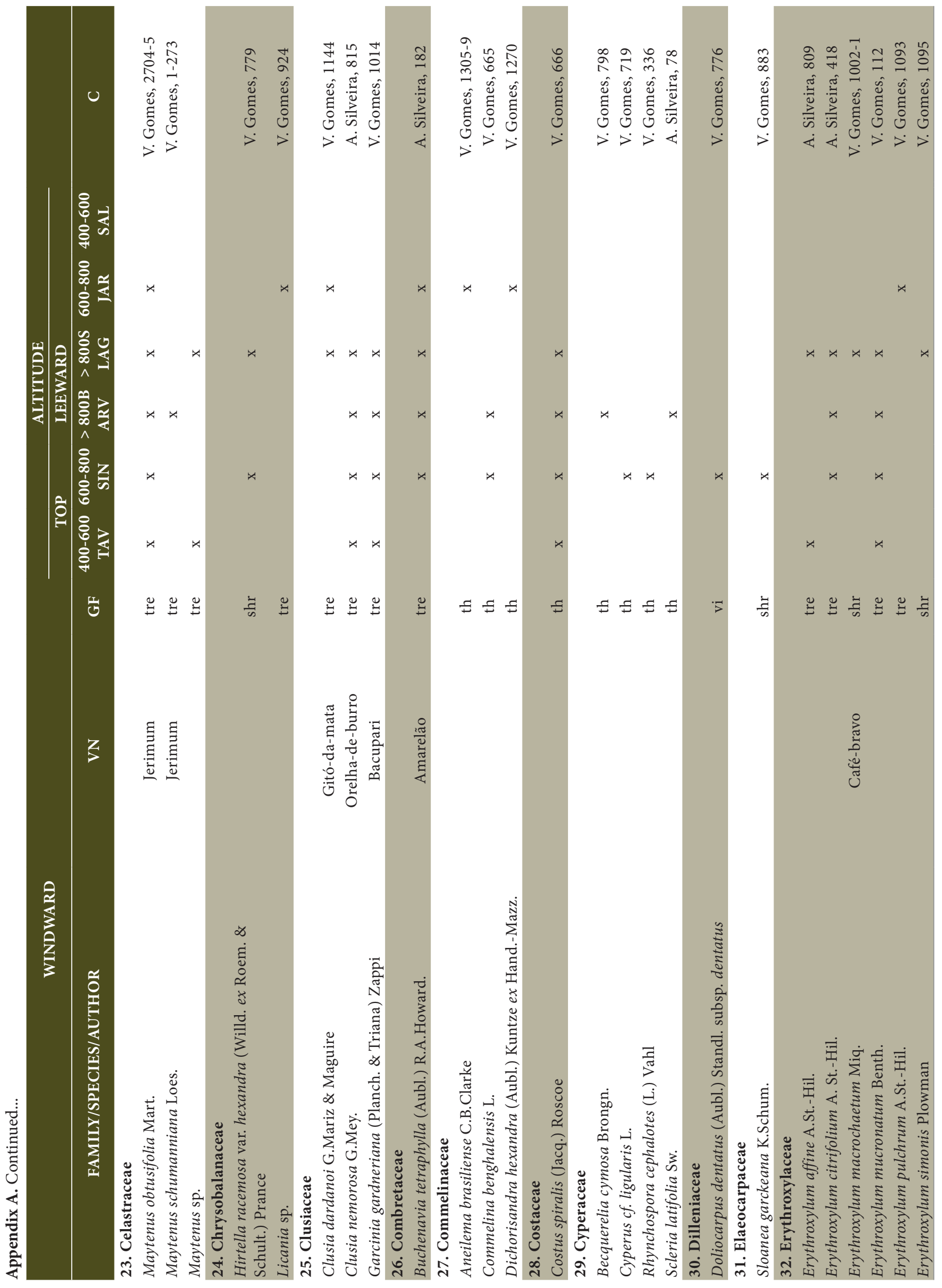




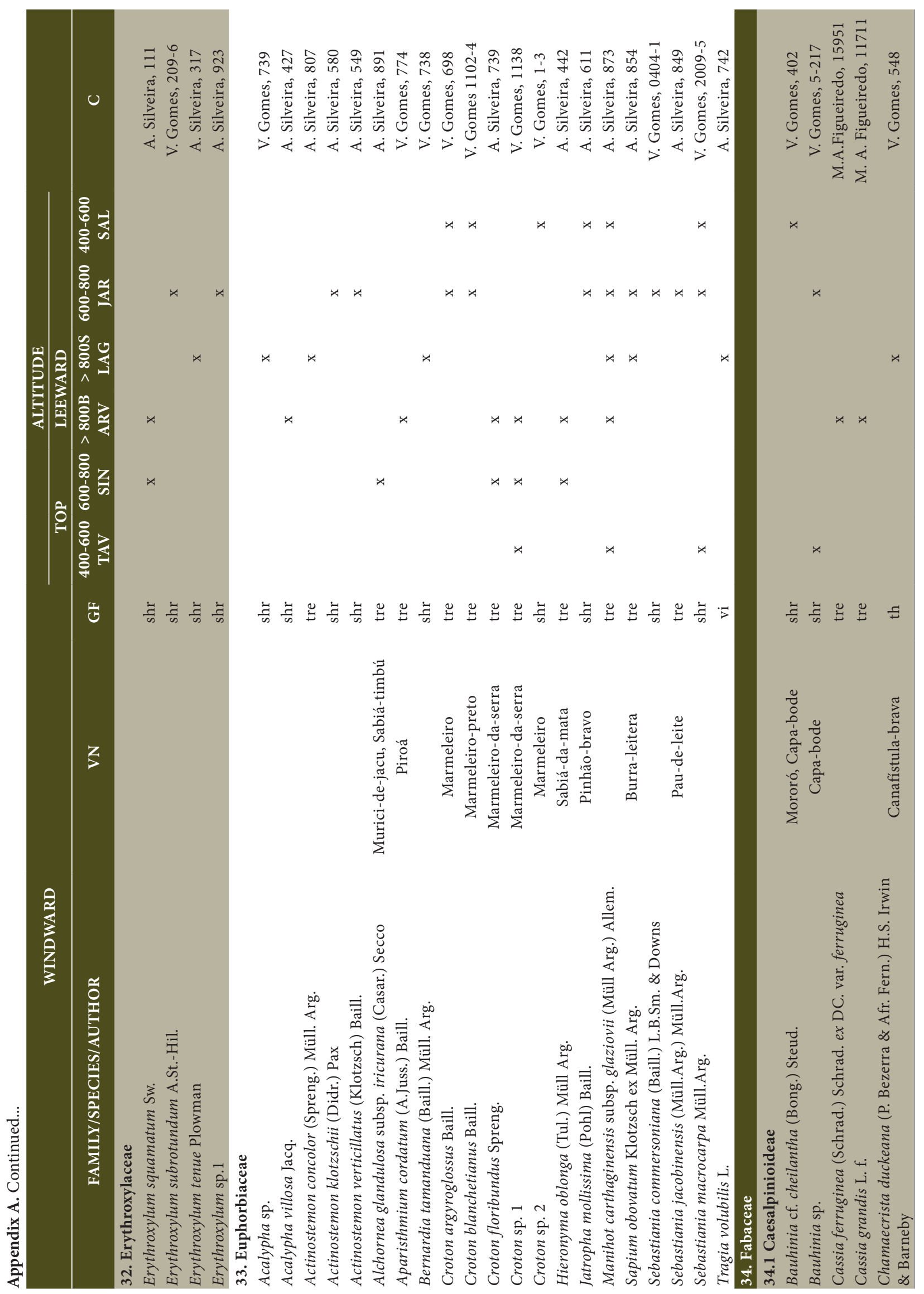




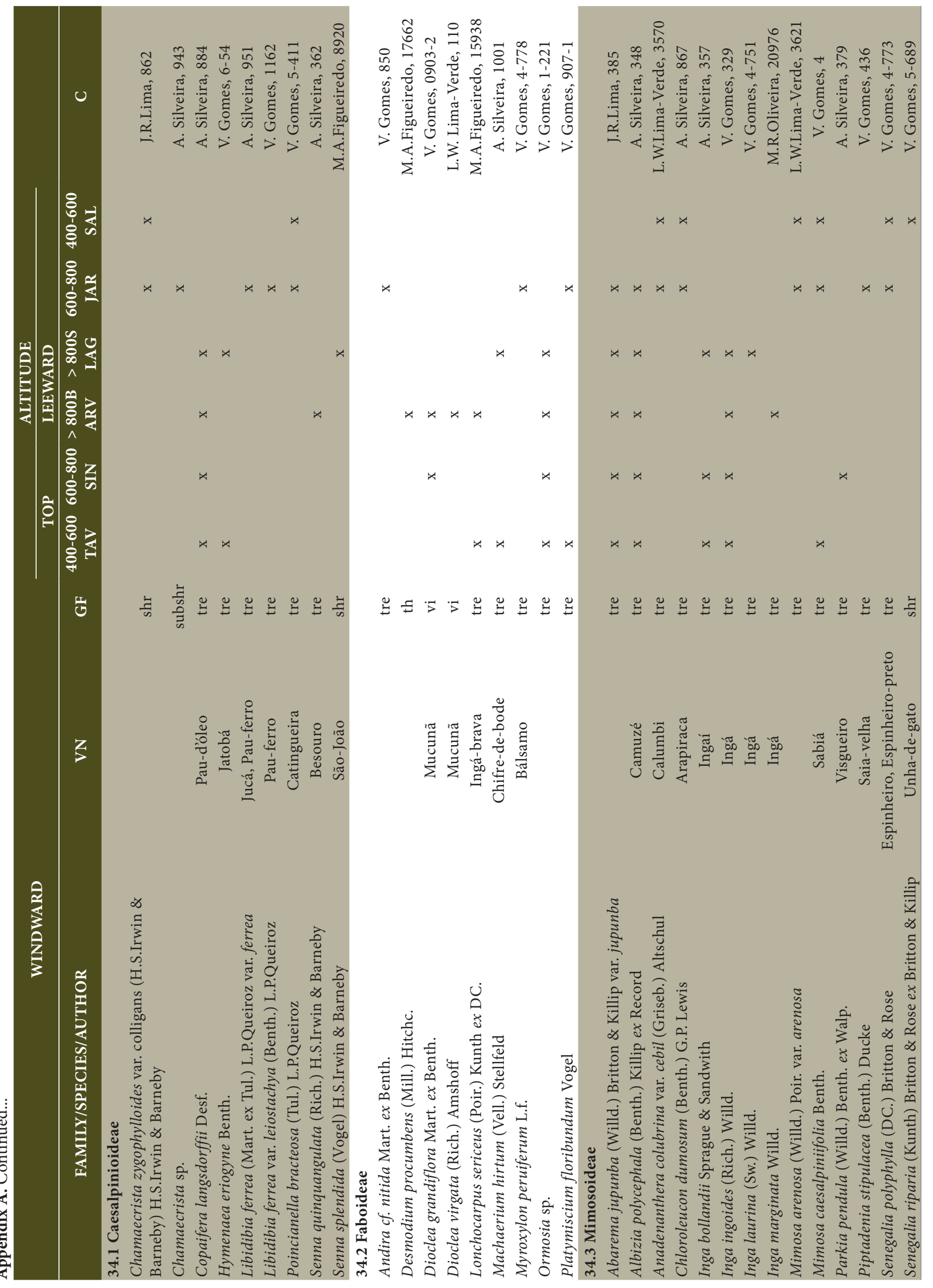




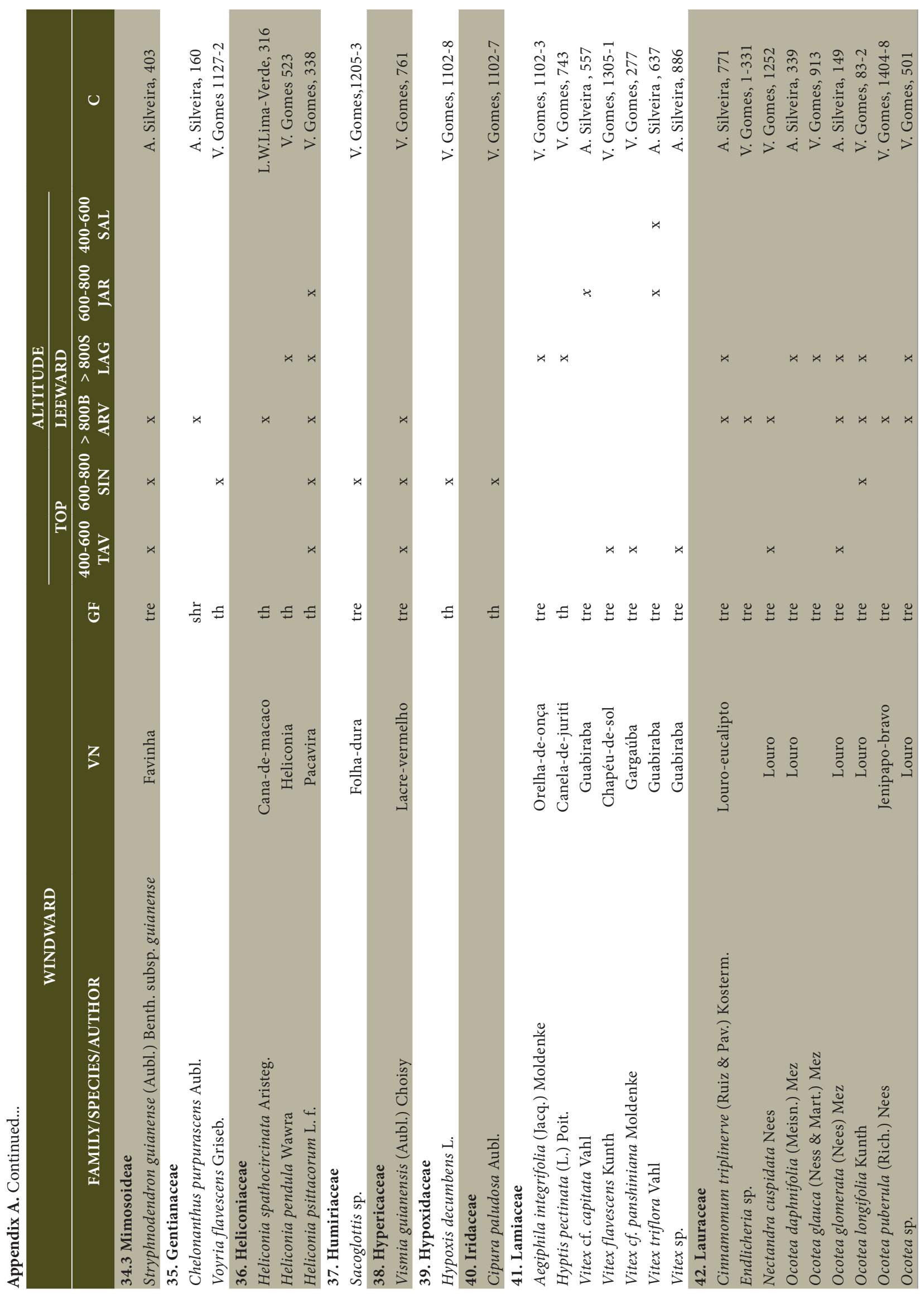




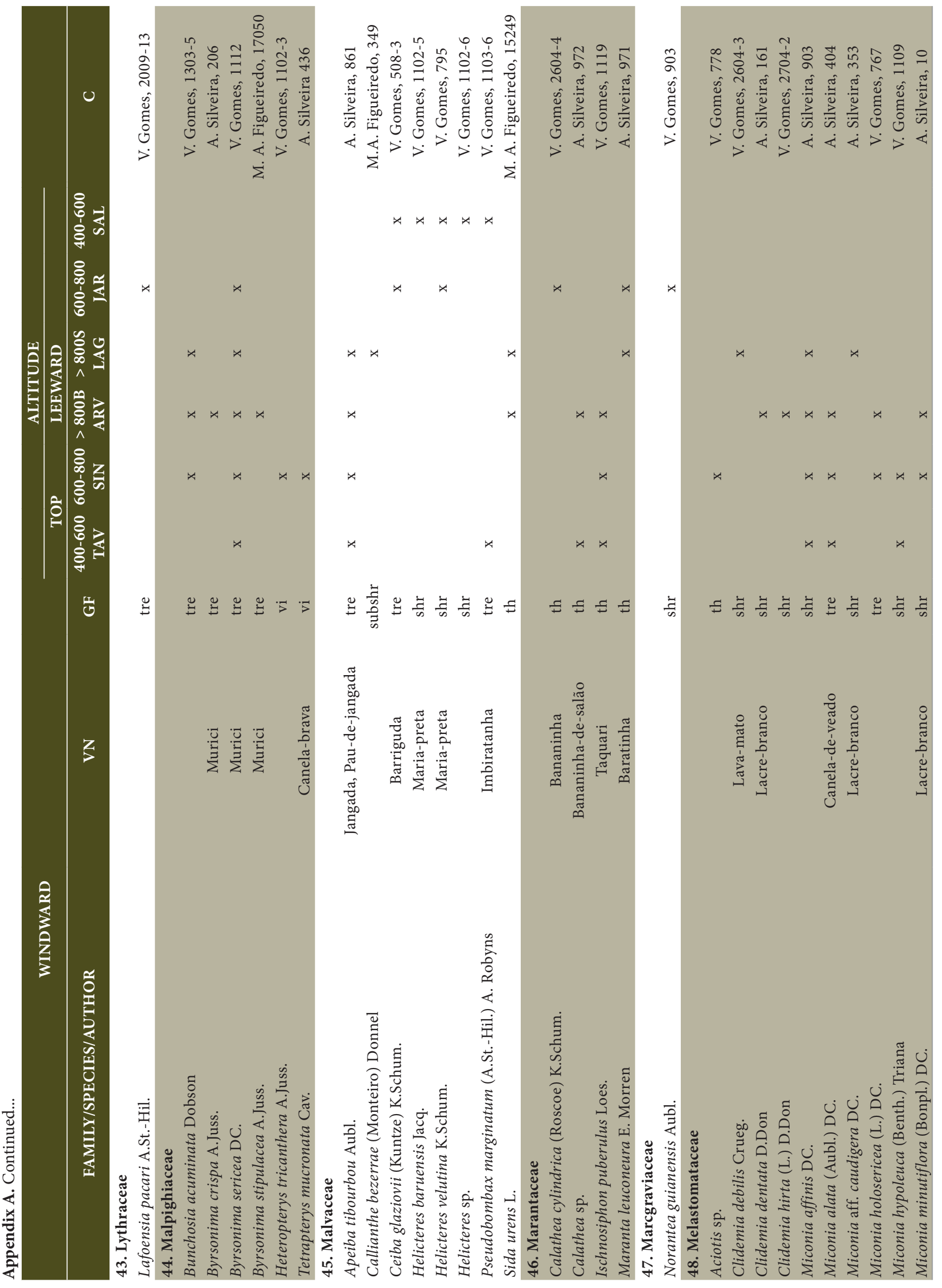




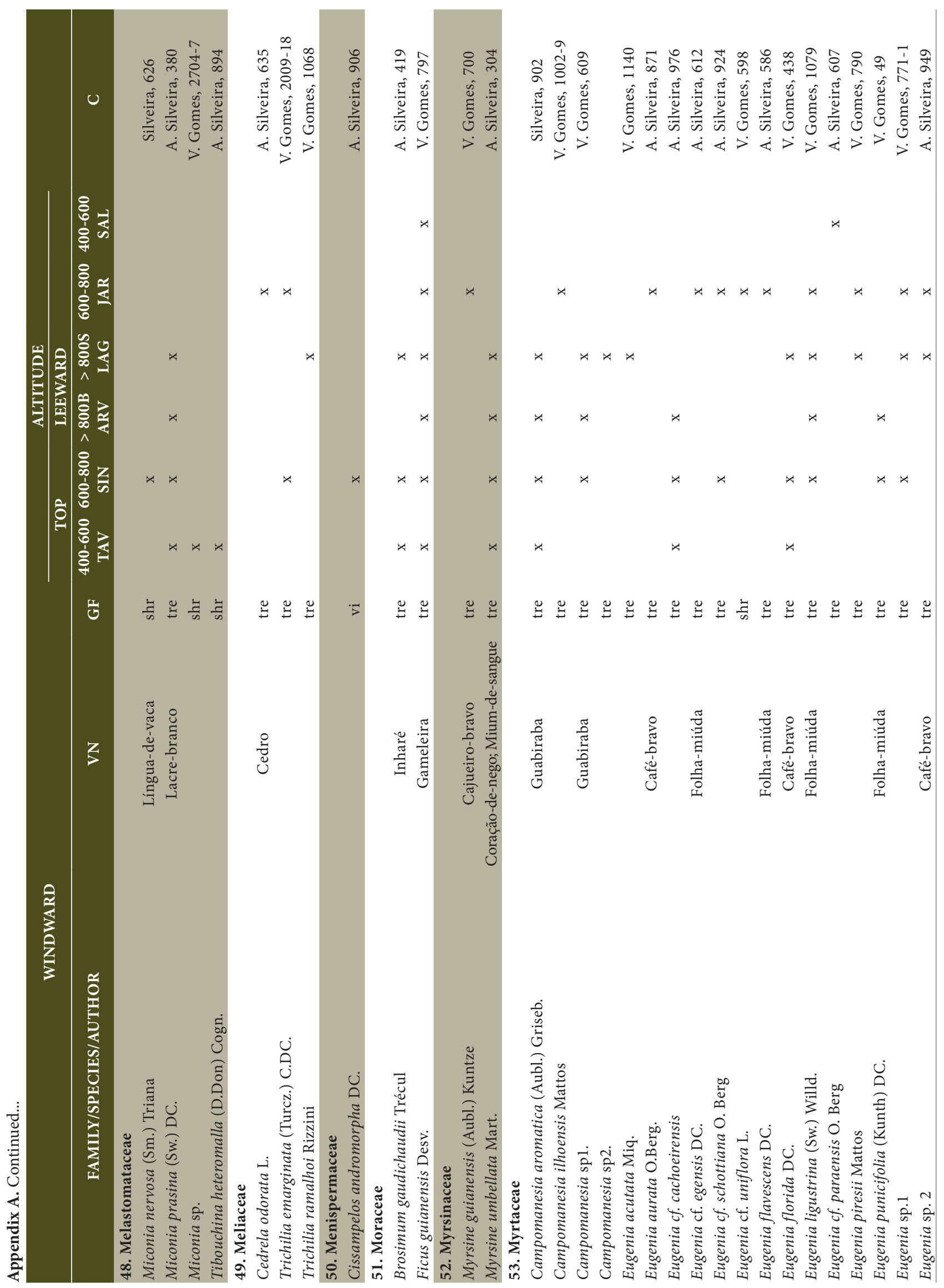




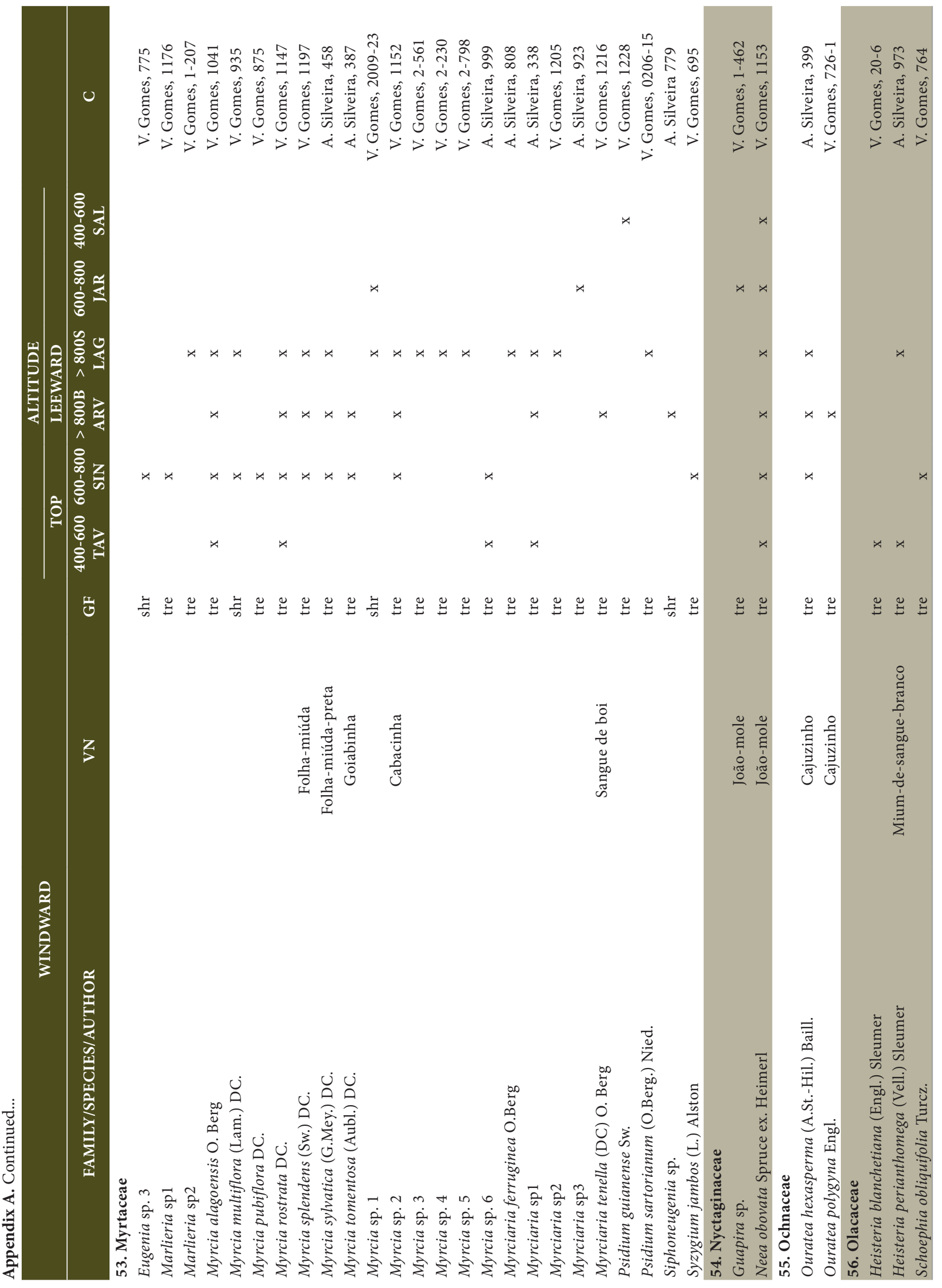




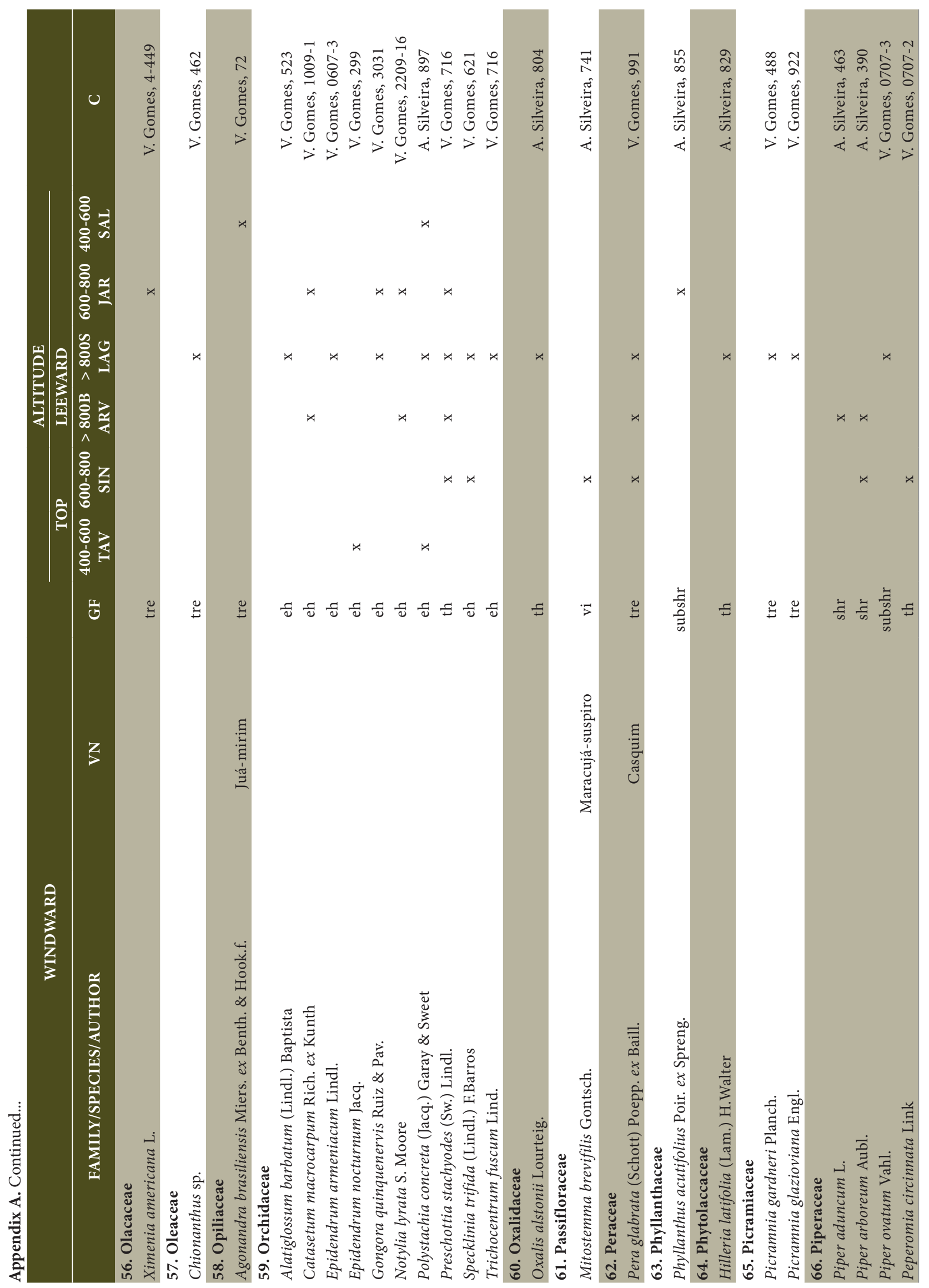




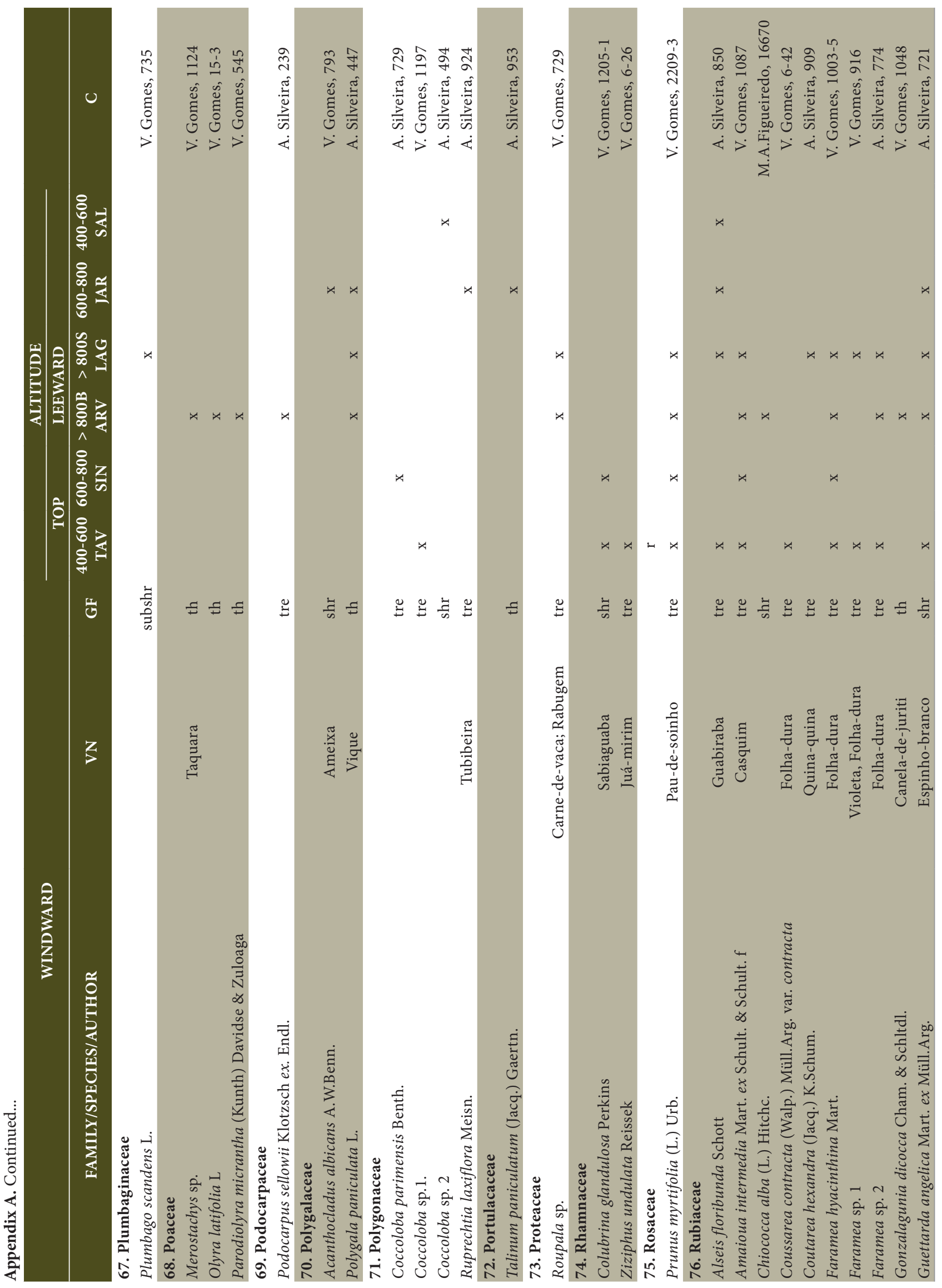




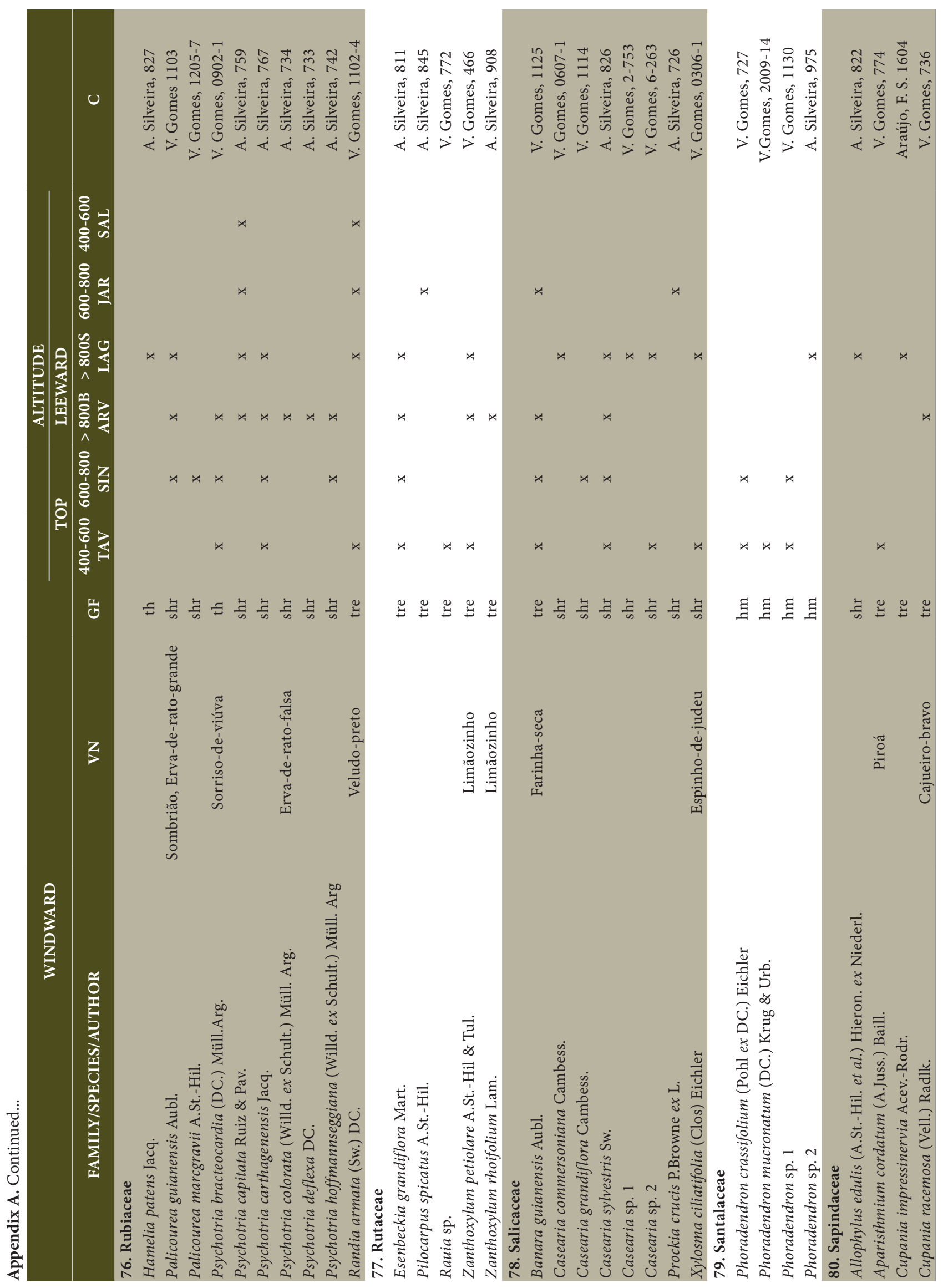




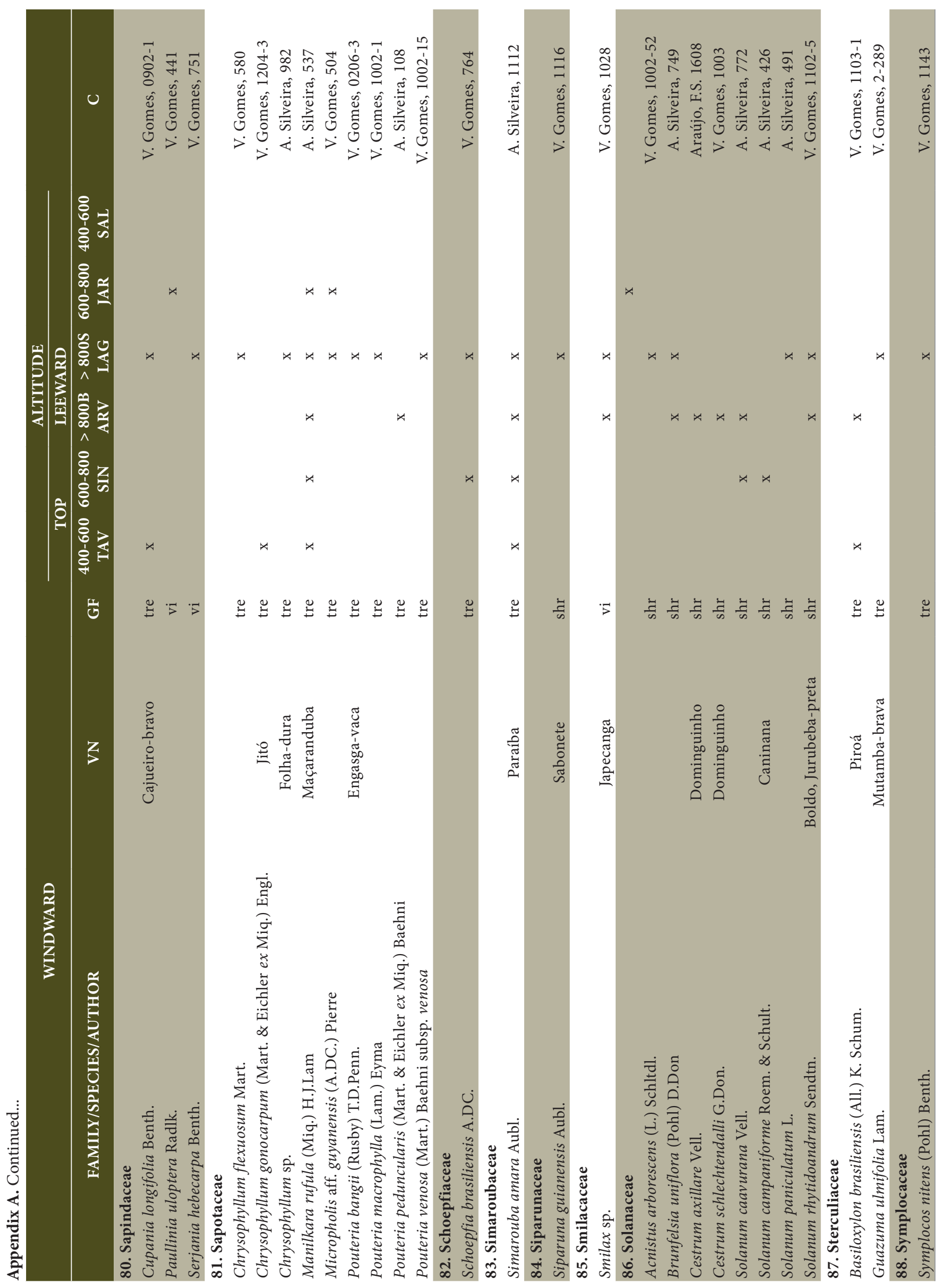




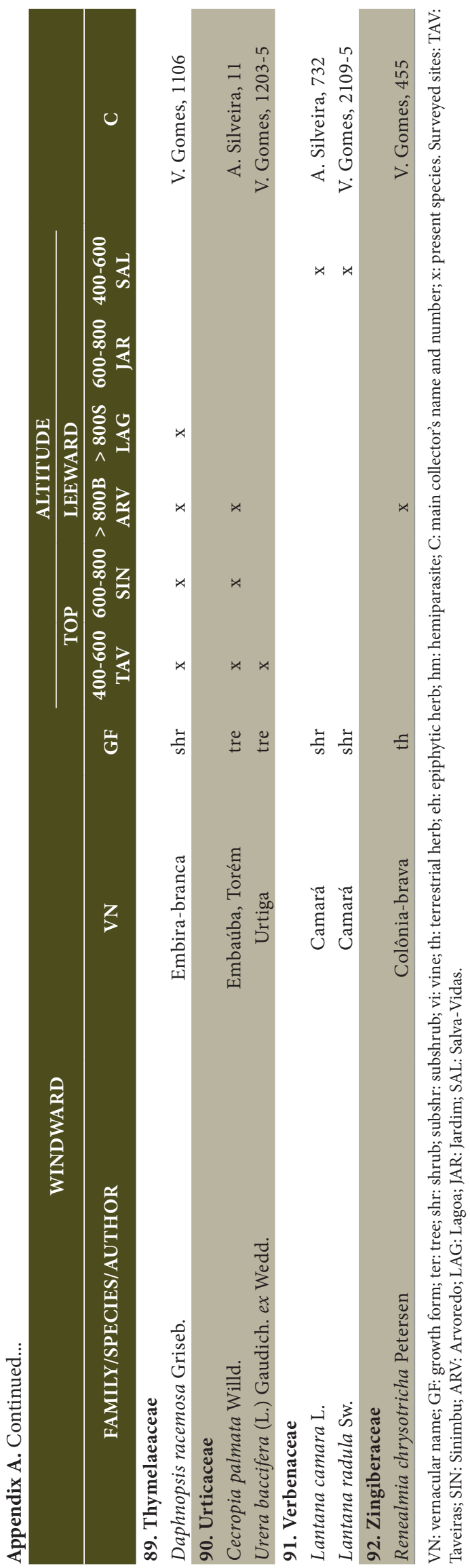

